\title{
Vascular Responsiveness to Angiotensin II and Phenylephrine, the Tubular Function and the Prostaglandin, Renin-Angiotensin System in a Patient with Bartter's Syndrome
}

\author{
Terunao Ashida, Toshiyuki Tanaka, Chikao Yutani,* Minoru Kawamura, Takashi MandaI,** \\ Masahito Imanishi, Genjiro Kimura, Shunichi Kojima, Keiichi Ito, Morio Kuramochi and Teruo Omae
}

In a 39-yr-old female patient with Bartter's syndrome, vascular responsiveness to angiotensin II and phenylephrine was studied. Pressor responses to angiotensin II and to phenylephrine were markedly decreased prior to treatment and were improved by administration of indomethacin, dextran, KCl, captopril, propranolol or pindolol. Moreover, the responses of total peripheral vascular resistence to angiotensin II and phenylephrine were markedly decreased before treatment and were improved by the treatment. A relatively low fractional distal chloride reabsorption was found, and that was not changed after the administration of $\mathrm{KCl}$ or indomethacin. The results of this patient were compatible with the primary cause of Bartter's syndrome, defective chloride reabsorption at the loop of Henle, but the possibility of an abnormality in the vascular wall could not be denied.

(Internal Medicine 31: 134-139, 1992)

Key words: indomethacin, captopril, propranolol, pindolol, total peripheral vascular resistance

\section{Introduction}

Bartter's syndrome, originally reported by Bartter et al (1) in 1962, has the characteristics of hyperplasia and hypertrophy of the juxtaglomerular apparatus, hyperreninemia, aldosteronism with hypokalemic alkalosis and normal blood pressure (BP) with decreased pressor responsiveness to intravenous infusion of angiotensin II (A II). The pathogenesis of this syndrome has not yet been established though several hypotheses have been proposed. Excessive renal production of prostaglandin in Bartter's syndrome was reported in $1976(2-4)$, and a defect in distal tubular reabsorption of chloride was observed in 1978 (5).

We have recently studied the vascular responsiveness to A II and phenylephrine, distal tubular reabsorption of chloride and the function of the endocrine system in a case of Bartter's syndrome, and studied the effects of treatments of potassium chloride $(\mathrm{KCl})$, indomethacin, low molecular dextran, captopril, pindolol and propranolol.

\section{Case Report}

A 39-yr-old Japanese housewife had been troubled with general fatigue and easy fatigability since the summer of 1981. She visited our hospital in December 1981. She had no known history of hypertension or edema. She had never received diuretics or laxatives. She was hospitalized in January 1982 for further examination of hypokalemia $(2.4 \mathrm{mEq} / 1)$, and a high level of plasma renin activity (PRA) $(7.5 \mathrm{ng} / \mathrm{ml} / \mathrm{h})$.

At the time of admission, her heart rate was 78 beats/ min and $\mathrm{BP}$ was $104 / 50 \mathrm{mmHg}$. Initial laboratory studies included low serum potassium $(2.2 \mathrm{mEq} / \mathrm{l})$, low serum chloride $(96 \mathrm{mEq} / 1)$, and also low serum magnesium $(1.5 \mathrm{mg} / \mathrm{dl})$. Electrocardiogram showed marked U-wave in leads $\mathrm{V}_{2-3}$. Arterial blood gas analysis revealed metabolic alkalosis with a $\mathrm{pH}$ of $7.462, \mathrm{HCO}_{3}{ }^{-}$of $27.2 \mathrm{mEq} / 1$ and a base excess of $+3.4 \mathrm{mEq} / \mathrm{l}$.

From The Division of Hypertension and Renal Disease, Department of Medicine, *Pathology and **Preventive Medicine, National Cardiovascular Center, Suita

Received for publication January 7, 1991; Accepted for publication May 24, 1991

Reprint requests should be addressed to Terunao Ashida, MD, Division of Hypertension and Renal Disease, Department of Medicine, National Cardiovascular Center, 5-7-1 Fujishiro-dai, Suita 565, Japan 
Regarding renal functional studies, the PSP test, glomerular filtration rate (GFR), intravenous pyelogram, renogram, renal scintigram, and computed tomography of the abdomen were all normal, though Fishberg's concentration test was slightly low in the maximum (750 mOsm/l).

\section{Methods}

The determination of fractional distal tubular chloride reabsorption was performed as described by Gill and Bartter (5), with the exception that endogenous creatinine clearance was used in place of inulin clearance to estimate the GFR. Urine samples were collected after voiding without catheterization.

The A II infusion study was performed as previously reported (6), before and during the treatments with dextran, $\mathrm{KCl}$, indomethacin, captopril, pindolol or propranolol. The infusion of A II was preceded by very slow intravenous administration $(20 \mathrm{ml} / \mathrm{h})$ of $5 \%$ dextrose for $30 \mathrm{~min}$. The dosage of A II $(0.8,2,4,8,16,20 \mathrm{ng} / \mathrm{kg} /$ $\mathrm{min} ; 1-13 \mathrm{ml} / \mathrm{h}$ ) was increased every $15 \mathrm{~min}$ until a rise in diastolic BP of at least $20 \mathrm{mmHg}$ was observed. BP was measured by automatic sphygmomanometer every $2 \mathrm{~min}$ in the preinfusion period and during the administration of A II. BP at each dose level was calculated by averaging the previous 4 or 5 determinations. Cardiac output was measured by impedance cardiography $(7,8)$ in the preinfusion period and during the administration of A II at each dose level. Total peripheral vascular resistance (TPR) was calculated from mean $\mathrm{BP}$ and cardiac output.

Phenylephrine was administered before and during the treatments with dextran, indomethacin, propranolol and pindolol. The dosage of phenylephrine $(0.08,0.16$, $0.32,0.64,1.28,2.56 \mu \mathrm{g} / \mathrm{kg} / \mathrm{min}$ ) was increased every 15 min. Cardiac output was measured and TPR was calculated by the same method as the A II infusion.

Captopril, an oral angiotensin-converting enzyme inhibitor, was orally administered in a single dose $(50 \mathrm{mg})$ $60 \mathrm{~min}$ before infusion of angiotensin II, because BP is almost stabilized $60 \mathrm{~min}$ after administration of captopril.

An A II analogue ( $\mathrm{Sar}_{1}-\mathrm{Ileu}_{8}$-A II) was administered for $10 \mathrm{~min}$ at a constant rate of $150 \mathrm{ng} / \mathrm{kg} / \mathrm{min}$, thereafter for $10 \mathrm{~min}$ at a rate of $300 \mathrm{ng} / \mathrm{kg} / \mathrm{min}$, and finally for $30 \mathrm{~min}$ at a rate of $600 \mathrm{ng} / \mathrm{kg} / \mathrm{min}$. Infusion of the A II analogue was repeated during the administration of indomethacin $(150 \mathrm{mg} /$ day $)$, which had been administered for 5 days. The patient received the last dose $(50 \mathrm{mg})$ of indomethacin $60 \mathrm{~min}$ prior to infusion of A II analogue.

$\mathrm{K}$ concentration in red blood cells (RBCs) was measured as follows: Blood was hemolyzed with 9 volumes of distilled water. The $\mathrm{K}$ concentration in serum and the hemolyzed blood was measured by flame photometry. K concentration in RBCs was calculated, using hematocrit and the $\mathrm{K}$ concentration in serum and the hemolyzed blood.

\section{Results}

Fractional distal tubular reabsorption of chloride

Gill and Bartter (5) reported that the chloride reabsorption rate of the distal tubule at maximum water diuresis is low (0.46) in Bartter's syndrome compared with a control group (0.92). The chloride reabsorption rate of the distal tubule at the maximum water diuresis in the present case was relatively low $(0.69)$ and it was not improved by treatment with $\mathrm{KCl}$ or indomethacin $(0.64$; 0.65 , respectively) (Table 1 ). The value of Japanese normal control subjects is reported to be $0.84 \pm 0.09$ (9) or $0.92 \pm 0.02(10)$.

While serum $\mathrm{K}$ concentration was $1.9 \mathrm{mEq} / \mathrm{l}$ before treatment, it was increased slightly by administration of dextran, pindolol and propranolol $(2.8,2.5,2.6 \mathrm{mEq} / 1$, respectively), and it became normal by administration of $\mathrm{KCl}$ and indomethacin $(4.2,3.6 \mathrm{mEq} / 1$, respectively). While urinary $\mathrm{K}$ excretion was $37 \mathrm{mEq} /$ day before treatment, it was decreased by administration of indomethacin ( $28 \mathrm{mEq} /$ day), and it was not changed by administration

Table 1. Fractional Distal Tubular Chloride Reabsorption before and during Treatment

\begin{tabular}{lccc}
\hline & $\begin{array}{c}\mathrm{U}_{\mathrm{Na}} \\
\text { (mEq/day) }\end{array}$ & $\begin{array}{c}\mathrm{U}_{\mathrm{k}} \\
\text { (mEq/day) }\end{array}$ & $\mathrm{C}_{\mathrm{H}_{2} \mathrm{O}}+\mathrm{C}_{\mathrm{Cl}}$ \\
\hline $\begin{array}{l}\text { Before treatment } \\
\mathrm{KCl} \text { (98 } \mathrm{mEq} / \text { day }\end{array}$ & 155 & 37 & 0.69 \\
for 20 days) & 196 & 109 & 0.64 \\
$\begin{array}{l}\text { Indomethacin }(150 \mathrm{mg} / \text { day } \\
\text { for 7 days) }\end{array}$ & 153 & 28 & 0.65 \\
\hline
\end{tabular}

$\mathrm{U}_{\mathrm{Na}}$, urinary sodium excretion; $\mathrm{U}_{\mathrm{k}}$, urinary potassium excretion; $\mathrm{C}_{\mathrm{H}_{2} \mathrm{O}}$, clearance of water; $\mathrm{C}_{\mathrm{Cl}}$, clearance of chloride; $\mathrm{C}_{\mathrm{H}_{2} \mathrm{O}} /\left(\mathrm{C}_{\mathrm{H}_{2} \mathrm{O}}+\right.$ $\mathrm{C}_{\mathrm{Cl}}$ ), fractional distal tubular chloride reabsorption.

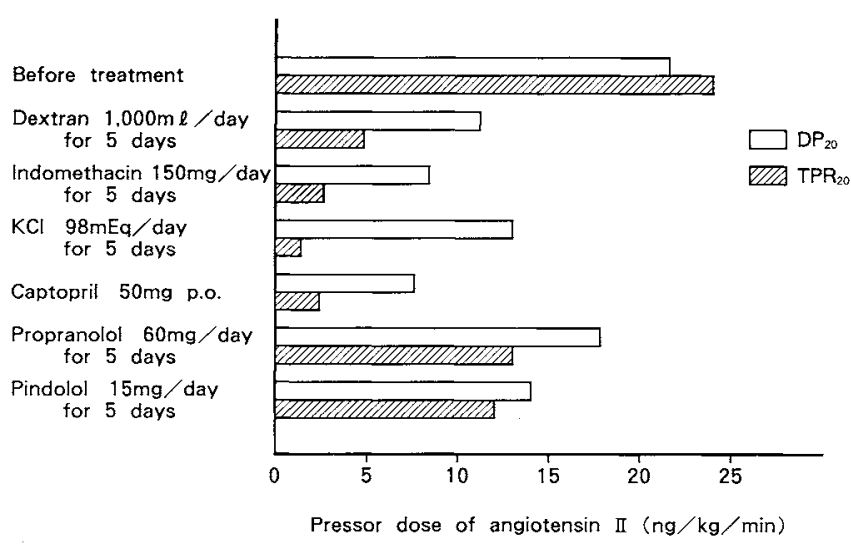

Fig. 1. Doses of angiotensin II required to produce a $20 \mathrm{mmHg}$ increase in diastolic blood pressure $\left(\mathrm{DP}_{20}\right)$ and required to produce a $20 \%$ increase in total peripheral vascular resistance $\left(\mathrm{TPR}_{20}\right)$ before and during treatment. 
of dextran ( $36 \mathrm{mEq} / \mathrm{day})$, but it was increased mildly by pindolol and propranolol (41, $46 \mathrm{mEq} /$ day, respectively). It was markedly increased by administration of $\mathrm{KCl}$ (109 mEq/day).

\section{Vascular responsiveness to angiotensin II}

A II infusion tests were performed both before and during administration of dextran, indomethacin, $\mathrm{KCl}$, captopril, propranolol, or pindolol to determine the dose of A II required to produce a $20 \mathrm{mmHg}$ increase in diastolic $\mathrm{BP}\left(\mathrm{DP}_{20}\right)$ and the dose of $\mathrm{A}$ II required to produce a $20 \%$ increase in TPR $\left(\mathrm{TPR}_{20}\right)$ (Fig. 1). Body weight was not changed by any of the treatments. While the $\mathrm{DP}_{20}$ of healthy adults was $5-10 \mathrm{ng} / \mathrm{kg} / \mathrm{min}$ of $\mathrm{A} \mathrm{II}$, $\mathrm{DP}_{20}$ of the patient was remarkably high before treatment $(21.4 \mathrm{ng} / \mathrm{kg} / \mathrm{min})$. After administration of low molecular dextran to increase the circulatory plasma volume, responsiveness to angiotensin II was improved $\left(\mathrm{DP}_{20} 11.1 \mathrm{ng} / \mathrm{kg} / \mathrm{min}\right)$. After administration of indomethacin, responsiveness to A II was remarkably improved $\left(\mathrm{DP}_{20} 7.5 \mathrm{ng} / \mathrm{kg} / \mathrm{min}\right) . \mathrm{KCl}$ and captopril also improved the responsiveness to $\mathrm{A}$ II $\left(\mathrm{DP}_{20} 13.0 ; 7.5 \mathrm{ng} /\right.$ $\mathrm{kg} / \mathrm{min}$, respectively). Both propranolol and pindolol slightly improved the responsiveness to A II $\left(\mathrm{DP}_{20} 17.8\right.$; $14.1 \mathrm{ng} / \mathrm{kg} / \mathrm{min}$, respectively). $\mathrm{TPR}_{20}$ was rermarkably improved during the administration of dextran, indomethacin, $\mathrm{KCl}$ or captopril compared with before treatment $(80,89,94,90 \%$, respectively) (Fig. 1). On the other hand, both propranolol and pindolol slightly improved $\mathrm{TPR}_{20}$ (45 and $49 \%$, respectively).

\section{Vascular responsiveness to phenylephrine}

Phenylephrine infusion tests were performed both before and during administration of dextran, indomethacin, propranolol or pindolol to determine $\mathrm{DP}_{20}$ and $\mathrm{TPR}_{20}$ (Fig. 2). While the $\mathrm{DP}_{20}$ of healthy adults was $0.6-1.4 \mu \mathrm{g} / \mathrm{kg} / \mathrm{min}, \mathrm{DP}_{20}$ of the patient was remarkably

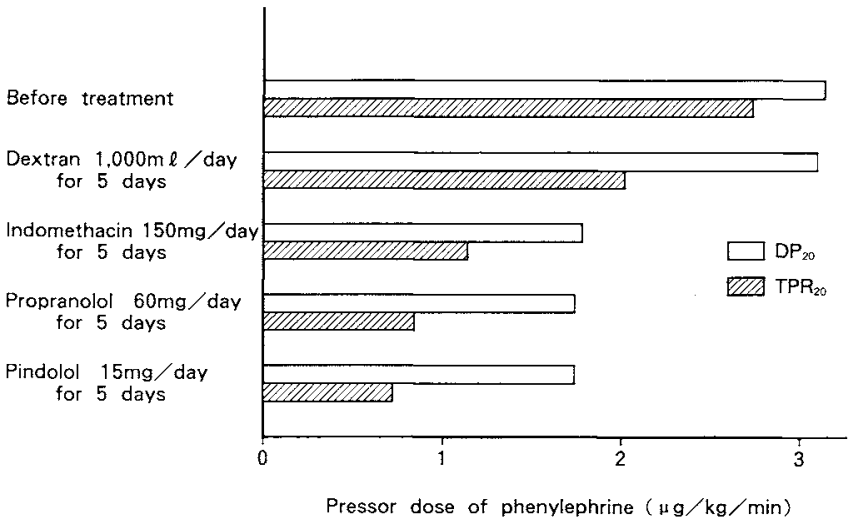

Fig. 2. Doses of phenylephrine required to produce a $20 \mathrm{mmHg}$ increase in diastolic blood pressure $\left(\mathrm{DP}_{20}\right)$ and required to produce a $20 \%$ increase in total peripheral vascular resistance $\left(\mathrm{TPR}_{20}\right)$ before and during treatment. p.o. $=$ per os.

high before treatment $(3.14 \mu \mathrm{g} / \mathrm{kg} / \mathrm{min})$. In spite of administration of low molecular weight dextran, $\mathrm{DP}_{20}$ was not changed. Indomethacin, propranolol and pindolol improved $\mathrm{DP}_{20}$ to the same extent $(1.77,1.75$ and $1.75 \mu \mathrm{g} / \mathrm{kg} / \mathrm{min}$, respectively). $\mathrm{TPR}_{20}$ was remarkably improved during the administration of propranolol, pindolol or indomethacin compared with before treatment ( 70,74 and $59 \%$, respectively). On the other hand, dextran slightly improved $\mathrm{TPR}_{20}(27 \%)$.

Before the infusions, the pressor doses of A II correlated with PRA, with a correlation coefficient of 0.80 (Fig. 3A). There was no correlation between the pressor doses of phenylephrine and PRA before infusion (Fig. $3 \mathrm{~B})$.

\section{Response to the converting enzyme inhibitor or angio-} tensin II analogue

The administration of captopril (50 mg p.o.) to the patient decreased BP extremely $(90 / 71 \mathrm{mmHg} \rightarrow 53 /$ $42 \mathrm{mmHg})$, markedly increased PRA $(25.8 \rightarrow 80.0 \mathrm{ng} /$
A.

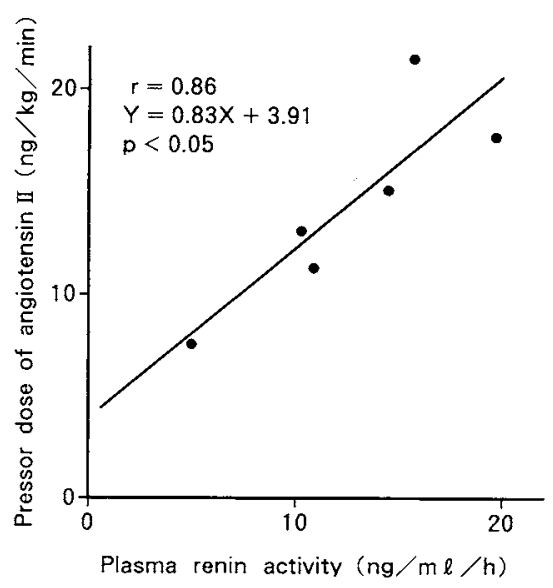

B.

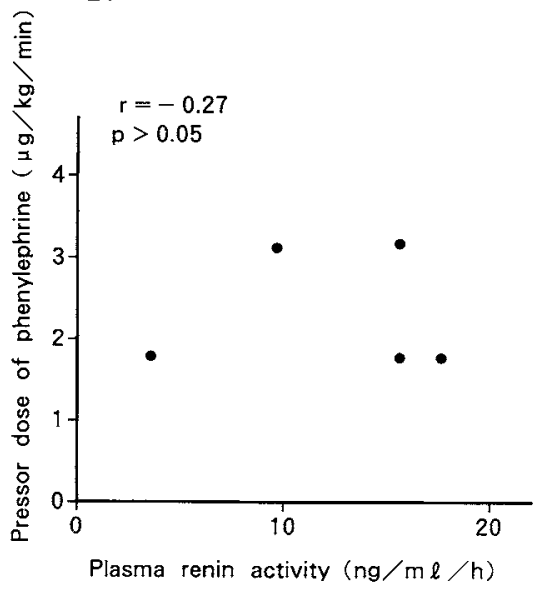

Fig. 3. Relation between plasma renin activity before infusion and the pressor doses of angiotensin II (A) and phenylephrine (B). Pressor dose $=$ dose of angiotensin II or phenylephrine required to produce a $20 \mathrm{mmHg}$ increase in diastolic blood pressure. 
$\mathrm{ml} / \mathrm{h}$ ) and mildly increased plasma aldosterone concentration $(\mathrm{PAC})(20.5 \rightarrow 32.5 \mathrm{ng} / \mathrm{ml})$. After the treatment with $\mathrm{KCl}$ tablets of $98 \mathrm{mEq} /$ day for 10 days, the administration of captopril $(50 \mathrm{mg}$ p.o.) markedly decreased BP $(89 / 64 \rightarrow 62 / 46 \mathrm{mmHg})$, markedly increased PRA $(7.2 \rightarrow 122.4 \mathrm{ng} / \mathrm{ml} / \mathrm{h})$ and decreased PAC $(10.9 \rightarrow$ $4.3 \mathrm{ng} / \mathrm{dl}$ ). While the infusion of A II analogue $\left(\operatorname{Sar}_{1}\right.$ Ileu $_{8}$ A II) $(150,300,600 \mathrm{ng} / \mathrm{kg} / \mathrm{min})$ induced a fall of BP before treatment $(102 / 71 \rightarrow 97 / 67,92 / 61$ and $82 /$ $54 \mathrm{mmHg}$, respectively), it conversely induced a slight rise of $\mathrm{BP}$ after the administration of indomethacin $150 \mathrm{mg} /$ day for 5 days $(104 / 66 \rightarrow 117 / 73,118 / 71$ and $117 /$ $72 \mathrm{mmHg}$, respectively). While the infusion of A II analogue increased PRA $(22.8 \rightarrow 104.0 \mathrm{ng} / \mathrm{ml} / \mathrm{h})$, PAC $(16.2 \rightarrow 22.8 \mathrm{ng} / \mathrm{dl})$ and cortisol $(7.1 \rightarrow 22.1 \mu \mathrm{g} / \mathrm{dl})$, it decreased PRA $(7.8 \rightarrow 5.4)$ and increased PAC $(5.2 \rightarrow$ $8.5 \mathrm{ng} / \mathrm{dl})$ after the administration of indomethacin $150 \mathrm{mg} /$ day for 5 days.

Response of plasma active and inactive renin activity and urinary prostaglandin $E_{2}$ excretion to indomethacin

Plasma active renin activity and inactive renin activity of this patient were extremely high (36.5 and $57.7 \mathrm{ng} /$ $\mathrm{ml} / \mathrm{h}$, respectively), and both were decreased remarkably by administration of indomethacin at $150 \mathrm{mg}$ /day for 5 days (3.36 and $12.2 \mathrm{ng} / \mathrm{ml} / \mathrm{h}$, respectively). Plasma active renin activity was also decreased by the administration of dextran to $10.2 \mathrm{ng} / \mathrm{ml} / \mathrm{h}$. Urinary prostaglandin $E_{2}$ excretion was slightly increased before treatment $(260 \mathrm{ng} /$ day; normal value: $<200 \mathrm{ng} /$ day), but it was remarkably decreased to $24 \mathrm{ng} /$ day by the administration of indomethacin. The plasma angiotensin converting enzyme activity was normal $(6.7 \mathrm{U} / \mathrm{l}$; normal value: $5-12 \mathrm{U} / \mathrm{l})$ before treatment, but it was slightly decreased to $4.6 \mathrm{U} / 1$ by the administration of indomethacin.

\section{Other hormonal and electrolyte measurements}

Both PAC and urine kallikrein excretion were elevated $(12.4 \mathrm{ng} / \mathrm{dl}$ and $5.66-9.04 \mathrm{EU} /$ day, respectively). Urine aldosterone, urine $17-\mathrm{OHCS}$, urine $17-\mathrm{KS}$, and urine catecholamine were normal. Rapid ACTH test showed a normal response. Not only the serum $\mathrm{K}$ concentration but also $\mathrm{K}$ concentration in RBCs were low $(2.5 \mathrm{mEq} / 1$ and $86.4 \mathrm{mEq} / \mathrm{l}-\mathrm{RBC}$, respectively) [normal control of $\mathrm{K}$ concentration in RBCs: $84.4 \pm 3.7 \mathrm{mEq} / \mathrm{l}-\mathrm{RBC}(\mathrm{n}=$ $5)$ ], and the ratio of $K$ concentration in $R B C s$ to the serum $\mathrm{K}$ concentration was remarkably high with a value of 35 [normal control: $22 \pm 1(\mathrm{n}=5)]$.

\section{Histologic findings}

Renal biopsy revealed hyperplasia of the juxtaglomerular apparatus (Fig. 4). High density homogeneous excretion granules were detected by electron microscropic examination (Fig. 5). The granules, with a diameter of $500 \mathrm{~nm}$ and a double membrance structure, were considered to be the renin granules. No abnormality

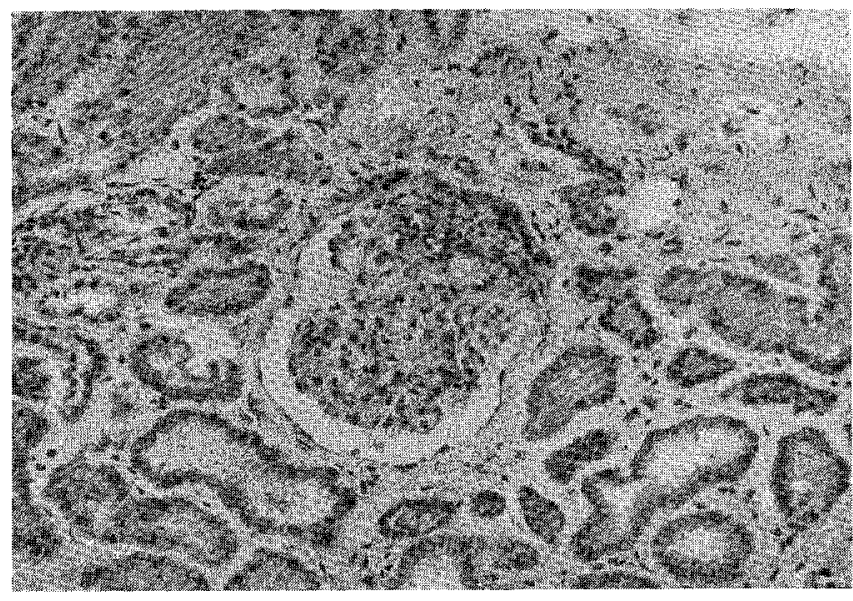

Fig. 4. Optical-microscopic photograph of the renal biopsy specimen. $\times 400$.

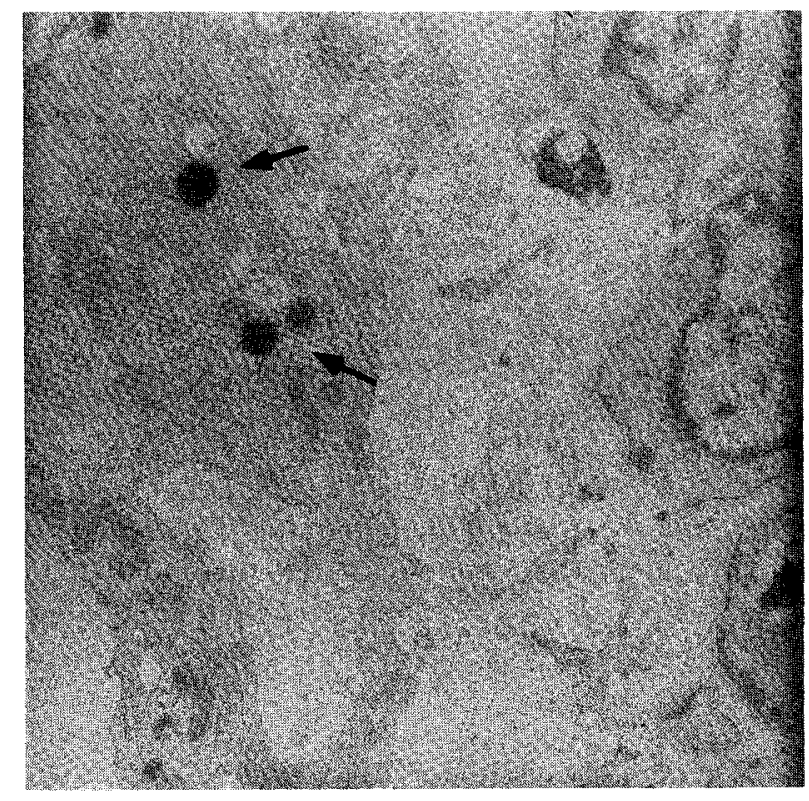

Fig. 5. Electron-microscopic photograph of the renal biopsy specimen. $\times 3,500$.

was detected in the chromosome analysis.

\section{Discussion}

The pathogenesis of Bartter's syndrome has been controversial. Among the hypotheses for the pathogenesis of this syndrome, several investigators favour the idea of a primary abnormality in chloride reabsorption in the thick ascending limb of Henle $(5,11,12)$. We examined the hypothesis of a defect of chloride reabsorption in the ascending limb of the loop of Henle. $\mathrm{C}_{\mathrm{H}_{2} \mathrm{O}} /\left(\mathrm{C}_{\mathrm{H}_{2} \mathrm{O}}+\mathrm{C}_{\mathrm{Cl}}\right)$, or the rate of reabsorption of chloride in the ascending limb of the loop of Henle, was relatively low (0.69). Moreover, it was not improved (0.65) after the administration of indomethacin $150 \mathrm{mg} /$ day, though urinary prostaglandin excretion was mark- 
edly inhibited. This means that indomethacin did not improve the decrease of the rate of chloride reabsorption in the ascending limb of the loop of Henle. The results of this patient were compatible with the results of Gill and Bartter (5). However, it has been recently reported that there are patients with this syndrome who have no defects of chloride reabsorption in the ascending limb of the loop of Henle $(9,13)$.

A subdivision of Bartter's syndrome into three groups has been proposed by Stein, based upon the presumed functional defect of the renal tubule (14). The psesent patient has a low magnesium level and therefore conforms to type III, which consists of a localized defect of sodium transport in the thick ascending limb of Henle's loop, and is associated with magnesium deficiency.

Other investigators have suggested that the abnormalities in Bartter's syndrome are due to an increased plasma level of prostaglandins and kinins $(4,15,16)$. In this case, the patient also showed a mild increase of urinary prostaglandin $E_{2}$ excretion. However, there are many reports against this hypothesis. Urinary prostaglandin $\mathrm{E}$ excretion is not increased is all patients of this syndrome. Even when urinary prostaglandin excretion is normalized by sufficient, long-term administration of prostaglandin synthetase inhibitors or spironolactone, serum $\mathrm{K}$ concentration is still low in many cases of this syndrome (17). Moreover, hypopotassemia itself may promote the production of renal prostaglandin. The changes in renal or urinary prostaglandin excretion have been considered to be rather secondary.

It has been postulated that the syndrome may be due to a universal defect in the cell membrance handling of sodium leading to a secondary stimulation of $\mathrm{Na}^{+}-\mathrm{K}^{+}$ATPase activity. It was reported that there is an increased pump density and a low cation turn-over rate per pump unit (18). In the present case, the ratio of the $K$ concentration in RBCs to the serum $K$ concentration was remarkably high. This appears to be compatible with the "increased Na pump" hypothesis.

A prominent feature of Bartter's syndrome is the decreased sensitivity of BP to A II. The vasoconstrictive action of norepinephrine has also been reported to be decreased in this syndrome. In the present case, the pressor and TPR responses to A II or phenylephrine were markedly decreased. The TPR responses to A II were markedly improved by $\mathrm{KCl}$, captopril, indomethacin and dextran, but not so improved by propranolol or pindolol (Fig. 1). On the other hand, the TPR responses to phenylephrine were markedly improved by pindolol, propranolol and indomethacin, but not by dextran (Fig. 2). Reeves et al (19) reported that the dose of A II necessary to increase the mean $\mathrm{BP}$ by $15 \mathrm{mmHg}$ was decreased $52 \%$ by propranolol or nadolol in 10 normal subjects. In the present case, the $\mathrm{DP}_{20}$ of $\mathrm{A}$ II was decreased only $17 \%$ by propranolol and only $34 \%$ by pindolol. Thus, there is a possibility that the improve- ment of the responses to A II by $\beta$ blockers is impaired in this patient. The improvement in the pressor and TPR responses to A II or phenylephrine might be mainly due to renal vasoconstriction, tubular retension of sodium, expansion of the circulatory volume or suppression of the renin-angiotensin axis. However, we cannot deny the possibility that there might be an abnormality in the contraction mechanism of the vascular wall, or in the synthesis of the vasodilator substitute, such as prostaglandin E or prostacyclin (20), in the blood vessel walls. Further examination will be necessary to clarify this possibility in the future.

In the present case, both captopril and A II analogue markedly decreased the BP and mildly increased PAC. A II analogue also increased serum cortisol. So there is the possibility that aldosterone secretion was mildly augmented by ACTH which had been increased by administration of captopril or A II analogue.

In summary, in this case of Bartter's syndrome, the results were compatible with the hypothesis that the main cause of this syndrome may be the defective chloride reabsorption at the loop of Henle, but the possibility of an abnormality in the vascular wall could not be denied.

\section{References}

1) Bartter FC, Pronove P, Gill JR Jr, MacCardle RC. Hyperplasia of the juxtaglomerular complex with hyperaldosteronism and hypokalemic alkalosis. Am J Med 33: 811, 1962

2) Verbeckmoes R, Van Damme B, Clement J, Amery A, Micheilsen P. Bartter's syndrome with hyperplasia of renomedullary cells. Successful treatment with indomethacin. Kidney Int 9: 302, 1976

3) Bartter FC, Gill JR Jr, Frolich JC, et al. Prostaglandins are overproduced by the kidneys and mediate hyperreninemia in Bartter's syndrome. Trans Assoc Am Physicians 89: 77, 1976

4) Gill JR Jr, Frohlich JC, Bowden RE, et al. Bartter's syndrome: A disorder characterized by high urinary prostaglandins and a dependence of hyperreninemia on prostaglandin synthesis. Am J Med 61: 43, 1976

5) Gill JR Jr, Bartter FC. Evidence for a prostaglandin-independent defect in chloride reabsorption in the loop of Henle as a proximal cause of Bartter's syndrome. Am J Med 65: 766, 1978

6) Ashida T, Nishioeda $Y$, Kimura G, et al. Effects of salt, prostaglandin, and captopril on vascular responsiveness in essential hypertension. Am J Hypertens 2: 640, 1988

7) Kinnen E. Cardiac output from transthoracic impedance variation. Ann NY Acad Sci 170: 747, 1970

8) Kubicek WG, Patterson RP, Witsoe DA. Impedance cardiography as a noninvasive method of monitoring cardiac function and other parameters of the cardiovascular system. Ann NY Acad Sci 170: 724, 1970

9) Ogihara $T$, Maruyama A, Nugent CA, Hata $T$, Mikami H, Kumahara Y. Familial Bartter's syndrome. Arch Intern Med 142: $906,1982$.

10) Taniguchi S, Suzuki J, Terai $Y$, Monma N, Satodate R, Suzuki Z. Pathogenesis of Bartter's syndrome with physiological and histological evaluation: A report of three cases in a sibship. Jpn J Nephrol 26: 1495, 1984.

11) Baehler RW, Work J, Kotchen TA, McMorrow G, Guthric G. Studies on the pathogenesis of Bartter's syndrome. Am J Med 69: 933, 1980.

12) Westenfelder C, Kurtzmann NA. Bartter's syndrome: A disorder 


\section{A Case of Bartter's Syndrome}

of active sodium and/or passive chloride transport in the thick ascending limb of Henle's loop. Miner Electrolyte Metab 5: 135, 1981.

13) Solomon LR, Bobinski H, Astley P, Goldby FS, Mallick NP. Bartter's syndrome - Observations on the pathophysiology. Q J Med 203: 251, 1982.

14) Stein JH. The pathogenetic spectrum of Bartter's syndorome. Kidney Int 28: 85, 1985.

15) Bowden RE, Gill JR Jr, Radfar N, et al. Prostaglandin synthetase inhibitors in Bartter's syndrome: Effect on immunoreactive prostaglandin E excretion. J Am Med Assoc 239: 117, 1978.

16) Mattioli $M$, Delva $P$, Lechi $A$, et al. Increased sodium-lithium countertransport in red cells of patients with Bartter's syndrome.
J Endocrinol Invest 7: 61, 1984.

17) Delany VB, Oliver JF, Simms M, et al. Bartter's syndrome: Physiological and pharmacological studies. Q J Med, New Ser L. 50: 213, 1981.

18) Jest P, Pedersen KE, Klitgaard NA, et al. Lymphocytic sodium and potassium pump function in Bartter's syndrome. Acta Endocrinol (Copenh) 121: 61, 1989.

19) Reeves RA, Boer WH, Deleve L, Leenen FH. Nonselective beta-blockade enhances pressor responsiveness to epinephrine, norepinephrine, and angiotensin II in normal man. Clin Pharmacol Ther 35: 461, 1984.

20) Bartter FC. Bartter's syndrome: A disorder of vascular reactivity. Hypertension 3 (Suppl I): I-69, 1981. 